\title{
Development of fragility curves for railway embankment and ballast scour due to overtopping flood flow
}

\author{
Ryota Tsubaki ${ }^{1}$, Jeremy David Bricker ${ }^{2}$, Koji Ichii $^{3}$, and Yoshihisa Kawahara ${ }^{3}$ \\ ${ }^{1}$ Department of Civil Engineering, Nagoya University, Furo-cho, Chikusa-ku, Nagoya 464-8603, Aichi, Japan \\ ${ }^{2}$ Delft University of Technology, Civil Engineering and Geosciences, P.O. Box 5048, 2600 GA Delft, the Netherlands \\ ${ }^{3}$ Department of Civil and Environmental Engineering, Hiroshima University, Kagamiyama 1-4-1, \\ Higashi-hiroshima 739-8527, Hiroshima, Japan \\ Correspondence to: Ryota Tsubaki (rtsubaki@ civil.nagoya-u.ac.jp)
}

Received: 13 May 2016 - Published in Nat. Hazards Earth Syst. Sci. Discuss.: 31 May 2016

Revised: 26 September 2016 - Accepted: 30 October 2016 - Published: 29 November 2016

\begin{abstract}
Fragility curves evaluating a risk of railway embankment fill and track ballast scour were developed. To develop fragility curves, two well-documented events of singletrack railway washout during floods in Japan were investigated. Type of damage to the railway was categorized into no damage, ballast scour, and embankment scour, in order of damage severity. Railway overtopping water depth for each event was estimated based on well-documented hydrologic and hydraulic analyses. Normal and log-normal fragility curves were developed based on damage probability derived from field records and the estimated overtopping water depth. A combined ballast and embankment scour model was validated by comparing the results of previous studies and the spatial distribution of railway damage type records.
\end{abstract}

\section{Introduction}

\subsection{Vulnerability of railways to floods}

Railway lines consist of components including tracks, power supply, and signaling infrastructure (Railway Technical Research Institute, 2007), all of which can suffer damage during river floods, hurricane storm surge, and tsunamis (e.g., Japan Railway Civil Engineering Association, 2000-2011), leading to interruption of transportation service (see Fig. 1 for two examples of damage due to surge in the USA). The most common mechanism of track damage occurs when tracks are overtopped by floodwaters, leading to scouring of the ballast and/or the embankment fill upon which the rail tracks are built (e.g., Brammer, 1990; Dawson et al., 2005). Even when only a short section of track is washed out, the entire railway system can experience serious delays or malfunction due to a ripple effect on the dispatch of engines and cars until the damaged section is repaired (Hong et al., 2015).

Since railcars (except those specialized for steep slopes like cable cars or rack railways) cannot handle steep gradients in topography, railways are often built in areas of mild slopes, such as rivers, floodplains, and coasts. Due to this, railway damage is a common occurrence during flood (e.g., Changnon, 2009; Kaneko, 2010; Polemio and Lollino, 2011; Tsubaki et al., 2012a) and storm surge (e.g., Steers et al., 1979; Bunya et al., 2010) events. Furthermore, railways utilize many bridges, which are often built with low clearance over waterways in order to minimize construction time, cost, and track slope. Many examples exist of such bridges collapsing during large river flood and tsunami events (e.g., Wardhana and Hadipriono, 2003; Reed, 2004; Kaneko, 2010).

As such, railways are seen to exhibit significant vulnerability when tracks are inundated or overtopped. Climate change projections show that in some locations, the frequency and intensity of river flood and storm surge events will increase (IPCC, 2014), further exacerbating risk to railway damage due to overtopping and inundation (Dawson et al., 2016). Predictive evaluation of railway damage due to flood is essential for concrete assessment of socioeconomic impact of large flood events.

In Japan, rapid population decline (Matanle, 2014; Cabinet Office, Government of Japan, 2016) is another factor ex- 

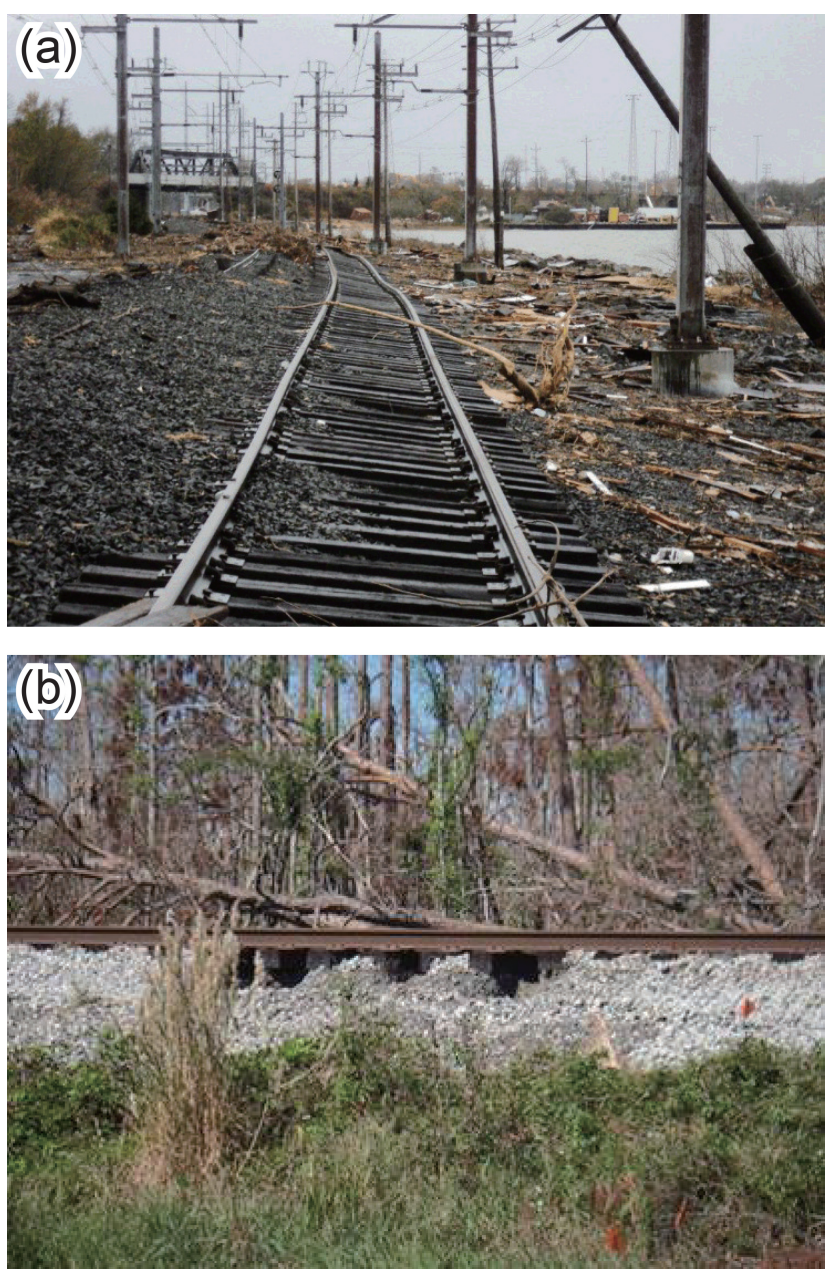

Figure 1. Railway ballast scour failures: (a) New Jersey Transit tracks in New Jersey, USA, after Hurricane Sandy in 2012; (b) CSX railroad tracks in Mississippi, USA, after Hurricane Katrina in 2005 (photo credits: New Jersey Transit, a).

acerbating risk to railways in many regions, as the amount of money available for maintenance and upgrade of these railways is shrinking together with the amount of customers and goods they serve to transport (Ministry of Land, Infrastructure, Transport and Tourism, 2015). Therefore, in order to prevent the need for expensive repairs after damage during future events, it is essential to evaluate which sections of railways are most vulnerable to washout during floods and to strengthen these sections before damage occurs.

\subsection{Current technological state of estimation of railway vulnerability and research need}

As discussed above, estimating the risk of railway damage due to flood is important subject to clearly understand the impact of large flood events but our knowledge about quantitative risk of railway damage is quite limited. As an example of this lack of knowledge, we would like to review the treat- ment of railway damage due to flood in a software package HAZUS (Federal Emergency Management Agency, 2010a).

This software package is developed for estimating potential losses caused by earthquakes, floods and hurricanes and widely used in the USA. Within the framework of HAZUS, a railway system consists of railway track/embankments, bridges, tunnels, stations, and other facilities (Federal Emergency Management Agency, 2010b, c). Table 1 summarizes the items accounted for in the flood sub-model in HAZUS-MH and corresponding valuation of these items (Scawthorn et al., 2006; Federal Emergency Management Agency, 2010c). In HAZUS, damage to railway tracks due to earthquakes is evaluated based on permanent ground deformation (Federal Emergency Management Agency, 2010a, 725 ), and the damage functions developed for major roads are adopted for damage estimation for railway tracks/roadbeds due to earthquake (Federal Emergency Management Agency, 2010a, 7-32). However, there is no guideline to estimate damage to railway tracks due to floods or hurricanes in the HAZUS framework. There have been several attempts to establish seismic failure prediction of railway components (e.g., Argyroudis and Kaynia, 2014) and river embankments (e.g., Hata et al., 2015), and river embankment failure due to overtopping (e.g., Dawson et al., 2005; Apel et al., 2009); however, railway track/embankment fragility due to flood overtopping is not yet implemented in practice (Federal Emergency Management Agency, 2010b). Hong et al. (2015) pointed out that development of the fragility model for railway embankment scour using detailed data collected from the field is a key challenge. Fundamental research on the processes responsible for railway embankment failure during floods has recently begun. For example, Polemio and Lollino (2011) reported a case of seepage failure of a railway embankment. Tsubaki et al. (2012b) experimentally investigated the onset and evolution of ballast scour.

Floods interact with and are controlled by the presence of embankments. There are even many locations in which transportation embankments serve as de facto river and coastal levees (e.g., Brammer, 1990; Dawson et al., 2005; Ueda and Nakatsuka, 2014). In such a location, if a flood causes an embankment scour, the flood will spread to previously protected areas. Therefore, in evaluating the risk of damage due to a railway embankment scour, it is important to evaluate the effect of that breach on the spread of the flood itself. Predicting the location of the railway embankment having significant potential to scour is essential to precisely evaluate the effect of the embankment scouring on the flood propagation during catastrophic flood events.

\subsection{Possible types of railway failure due to flooding}

To predict the probability of railway failure, the process of the failure should be specified. This paper focuses on fragility estimation of railway track/embankment scour due to overtopping. Even though railway embankments are ge- 
ometrically similar to roadway embankments and levees, the structures atop railway embankments are very different from those atop these other embankments, as are the mechanisms by which overtopping can cause damage. As Fig. 2 shows, floods can cause damage to railway embankments via three processes: (a) scour of ballast induced by overtopping, (b) scour of both ballast and embankment fill by overtopping, and (c) piping/seepage failure of embankment fill. Though piping/seepage failure of fill is more likely to occur in high (and wide) embankments, most railway embankments are relatively low, and most observed railway embankment failures appear to have been the result of overtoppinginduced scour of embankment fill and/or ballast (Kaneko, 2010; Tsubaki et al., 2012a; Onoda and Hayano, 2015). Ballast scour is a damage mode unique to railway embankments. In the cases of ballast scour only, repair of the ballast layer is relatively straightforward, but in cases of embankment fill scour, repairs can be costly and take a long time. Repair of damage to an embankment is less expensive than repair of damage to bridges and other facilities (see Table 1), but ballast and embankment damage occurs much more frequently than bridge damage. Furthermore, river floods or tsunamis large enough to damage bridges usually also cause extensive flooding which leads very long sections of an embankment to wash out (e.g., Shimozono and Sato, 2016). Therefore, the development of fragility curves for scour of railway ballast and embankments is crucial for the assessment of railway vulnerability and resilience.

\subsection{Fragility curve concept and its application to railway failure due to flooding}

In this study, the fragility curve concept (e.g., Shinozuka et al., 2000) is used to estimate the damage occurrence on railway ballast and embankment due to flood. Fragility curves are widely used to evaluate the vulnerability of structures in terms of probability. This approach was initially applied for seismic damage to bridges and other structures (Shinozuka et al., 2000; Ichii, 2002; Hata et al., 2015), and application to water-related hazards has followed (e.g., Hall et al., 2003 for national-scale flood risk assessment; Vorogushyn et al., 2009 for embankment piping failure; Suppasri et al., 2011 for building damage due to tsunami). Dawson et al. (2005) and Apel et al. (2009) utilized the fragility curve concept to estimate expected damage on river embankments due to overtopping. The damage probability of an embankment is dependent on the soil properties; these properties are highly variable in space and have large uncertainty (e.g., Apel et al., 2004; Dawson et al., 2005) though this uncertainty was accounted for in the shape of fragility curves in those studies. Railway embankment failures are also dependent on the soil properties. Ballast scour is, however, expected to have less variability in failure probability because the ballast material, embankment fill material, shape of embankment, rails, and sleepers are highly standardized in the industry, and their

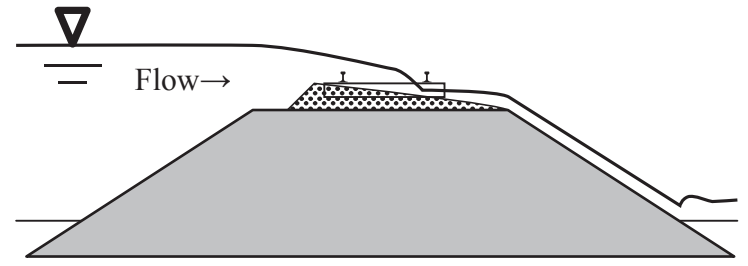

(a) Ballast scour

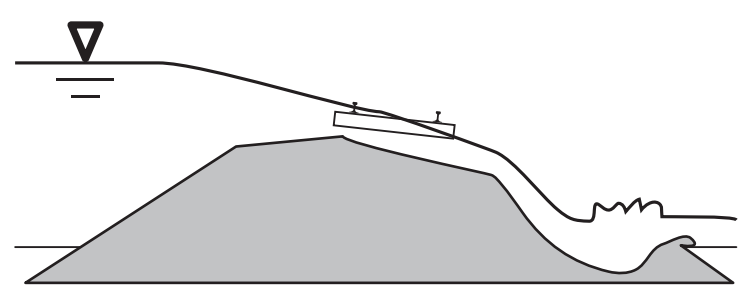

(b) Embankment scour

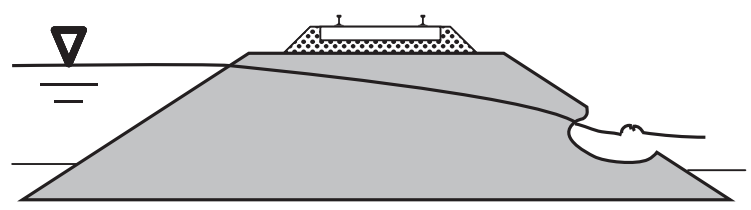

(c) Embankment seepage

Figure 2. Railway embankment damage types.

Table 1. Railway system classifications of the Federal Emergency Management Agency (2010b).

$$
\text { Occupancy }
$$

HAZUS valuation in thousands of USD

\begin{tabular}{lc}
\hline Railway tracks (per km) & 1500 \\
\hline $\begin{array}{l}\text { Railway bridge } \\
\text { (concrete, steel, wood, and unknown types) }\end{array}$ & 5000 \\
\hline Railway tunnel & 10000 \\
\hline $\begin{array}{l}\text { Railway urban station } \\
\text { (concrete, steel, wood, and brick made) }\end{array}$ & 2000 \\
\hline $\begin{array}{l}\text { Railway fuel facility } \\
\text { (tanks) }\end{array}$ & 3000 \\
\hline $\begin{array}{l}\text { Railway dispatch facility } \\
\text { (equip) }\end{array}$ & 3000 \\
\hline
\end{tabular}

Railway maintenance facility (concrete, steel, wood, and brick made) 


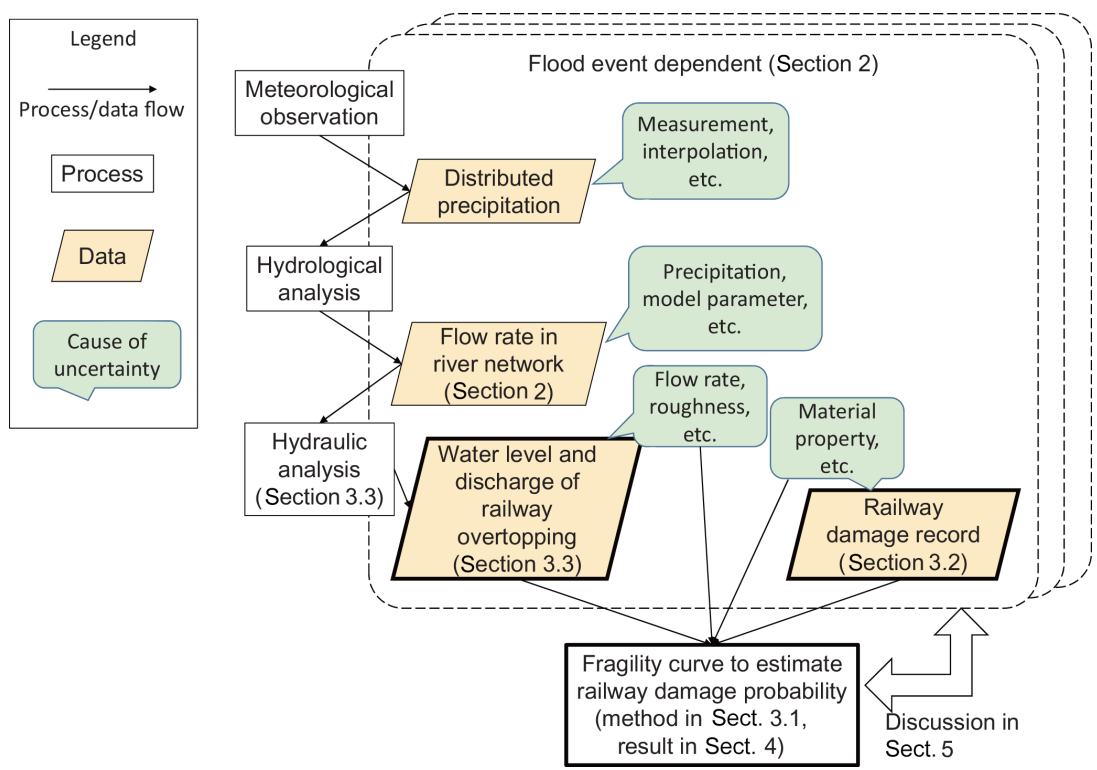

Figure 3. Relationship between processes and data within the structure of this paper.

condition is subject to frequent inspection and maintenance (e.g., Railway Technical Research Institute, 2007). So we can expect that the spatial variation in ballast failure criteria is substantially uniform compared with failure of non-railway embankments.

\subsection{Focus of this study: the first development of fragility curves for railway embankment and ballast scour}

This paper investigates the conditions responsible for scour of embankment fill and track ballast for single-track, unelectrified railways; these types of damage are quite common in rural areas where the level of flood protection is relatively limited. The fragility curves for this kind of railway embankment are developed based on two well-documented rail track washout events during recent floods in Japan.

Figure 3 shows the relationship between the processes and data used in this study. The two flood events for which damage records exist, as well as the estimated flow rates in the river networks during these events, are described in Sect. 2. Section 3 is devoted to the methods used in this study. Fragility curves are introduced in Sect. 3.1. Railway damage recorded for the two flood events is described in Sect. 3.2. The method of hydraulic analysis and uncertainty in the estimated water depth are both described in Sect. 3.3. Based on the results of Sects. 3.2 and 3.3, the fragility curves are developed in Sect. 4. Discussions including the comparison between the estimated damage probability and recorded damage types are reported in Sect. 5. Section 6 highlights the conclusions of this study.

\section{Target events}

In this section, two flood events and their accompanying railway scour damage are described. These two events were selected because of ready availability of existing information about meteorological conditions, hydrological and hydraulic analyses of the precipitation-run-off-flood process, and documentation of the railway damages. The two railway lines damaged during these events were both single-track, unelectrified railways.

\subsection{Asa River flood of July 2010}

In June 2010, a large flood occurred along section M (see Fig. 4) of the Asa River and caused inundation of homes and a factory, as well as washout of a railway embankment (Yamasaki et al., 2010; Tsubaki et al., 2014). The left-hand map in Fig. 4 outlines the watershed upstream of section M of the Asa River in red, while the watershed of the entire reach of the Asa River is outlined in orange. A storage function model, with parameters calibrated to previous major events, was used to calculate an event-dependent model parameter Rsa (a saturation criterion to start runoff), which was determined via best fit to the discharge hydrograph measured at the Asa Bridge gauge station (location indicated in the left panel of Fig. 4) based on four error criteria (Ube Construction Office, 2012). The estimated maximum flow rate in the Asa River was $811 \mathrm{~m}^{3} \mathrm{~s}^{-1}$ (Ube Construction Office, 2012), while the inflow from the Zuiko River was $110 \mathrm{~m}^{3} \mathrm{~s}^{-1}$. Though it is possible that the peak flow in each river would reach their confluence at slightly different times, the same hydrologic model showed that the maximum flow at a point $3 \mathrm{~km}$ downstream of the confluence was 


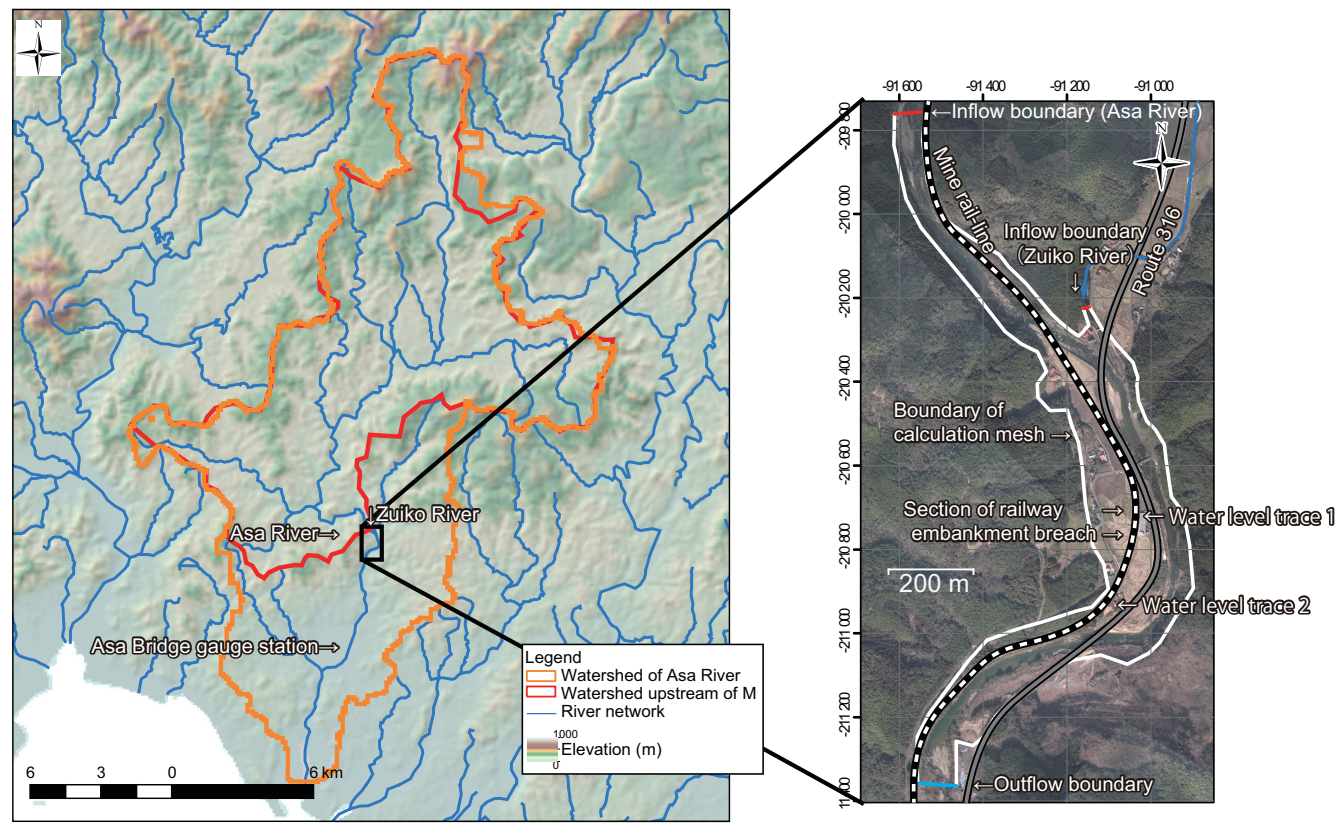

Figure 4. Watershed of the Asa River (left) and aerial photo taken in 2011 of section M (right). (Source: National Land Numerical Information download service, Ministry of Land, Infrastructure, Transport and Tourism, Japan, for digital elevation model, watersheds, and river network.)

$967 \mathrm{~m}^{3} \mathrm{~s}^{-1}$. This flow rate closely matches the peak flow rate of $957 \mathrm{~m}^{3} \mathrm{~s}^{-1}$ which was estimated from high water marks measured in the field. This implies the estimated flow rate is reasonable and the maximum flow rates of the Asa River and the Zuiko River converged almost simultaneously since no major tributaries exist between the confluence of the two rivers and this measurement point. Accordingly, flow rates of $811 \mathrm{~m}^{3} \mathrm{~s}^{-1}$ for the Asa River and $110 \mathrm{~m}^{3} \mathrm{~s}^{-1}$ for the Zuiko River are adopted as steady inflow boundary conditions for the hydraulic model of section $\mathrm{M}$.

\subsection{Sayo River flood of August 2009}

On 8-11 August 2009, Typhoon Etau generated record rainfall over the mid-west region of Japan including Sayo Town, Hyogo Prefecture. The previous $24 \mathrm{~h}$ record rainfall in Sayo Town had been $187 \mathrm{~mm}$, but Typhoon Etau set a new record at $327 \mathrm{~mm}$. This caused record flooding in the Chikusa River, the watershed of which includes Sayo Town and much of western Hyogo Prefecture, resulting in a large number of casualties, as well as extensive damage to river and slope protection works (Tsubaki et al., 2012a).

Figure 5 (left panel) illustrates the watershed upstream of section $\mathrm{S}$ of the Sayo River, together with that of its primary river, the Chikusa River. Figure 5 (right panel) depicts the domain in which the hydraulic flood model was evaluated. A rainfall-runoff simulation was conducted for the Sayo River basin upstream of the Enkouji gauge station (location indicated in the left panel of Fig. 5) (Tsubaki et al., 2012a; Fujita et al., 2014). A $50 \mathrm{~m}$ resolution distributed model that simulates both rainfall-runoff processes from mountainous slopes and flood routing in river channels based on the kinematic wave equations (Tachikawa et al., 2006; Sayama et al., 2010) was used to estimate the runoff during the event. The equations applied to the mountainous slopes were the lateral components of unsaturated and saturated subsurface and surface flows and the water mass balance equation (Tachikawa et al., 2006; Sayama et al., 2010). The Enkouji gauging station is located $1 \mathrm{~km}$ downstream of section $\mathrm{S}$ and the observed peak runoff was $1360 \mathrm{~m}^{3} \mathrm{~s}^{-1}$. The peak discharge estimated by the model was $1320 \mathrm{~m}^{3} \mathrm{~s}^{-1}$. The highest flow rate that passed through here during the August 2009 storm at the upstream boundary in the subdomain depicted in the right panel of Fig. 5 was calculated to be $750 \mathrm{~m}^{3} \mathrm{~s}^{-1}$ (Fujita et al., 2014; Tsubaki et al., 2012a).

\section{Methods}

\subsection{Fragility curve}

In this paper, we use upstream flood water level (overtopping surcharge) as a variable explanatory for railway overtopping failures. As schematically depicted in Fig. 6, under the situation of water overtopping an embankment, critical flow occurs on the embankment (C.S. in Fig. 6) and the upstream water level correlates almost directly to the overtopping discharge (Chow, 1959; Dawson et al., 2005; Apel et al., 2009). The upstream water has less velocity head and the surface is relatively flat, whereas the overtopping flow atop the embankment is rapidly varied flow and quite sensitive to small differences and uncertainty in the local elevation of the em- 


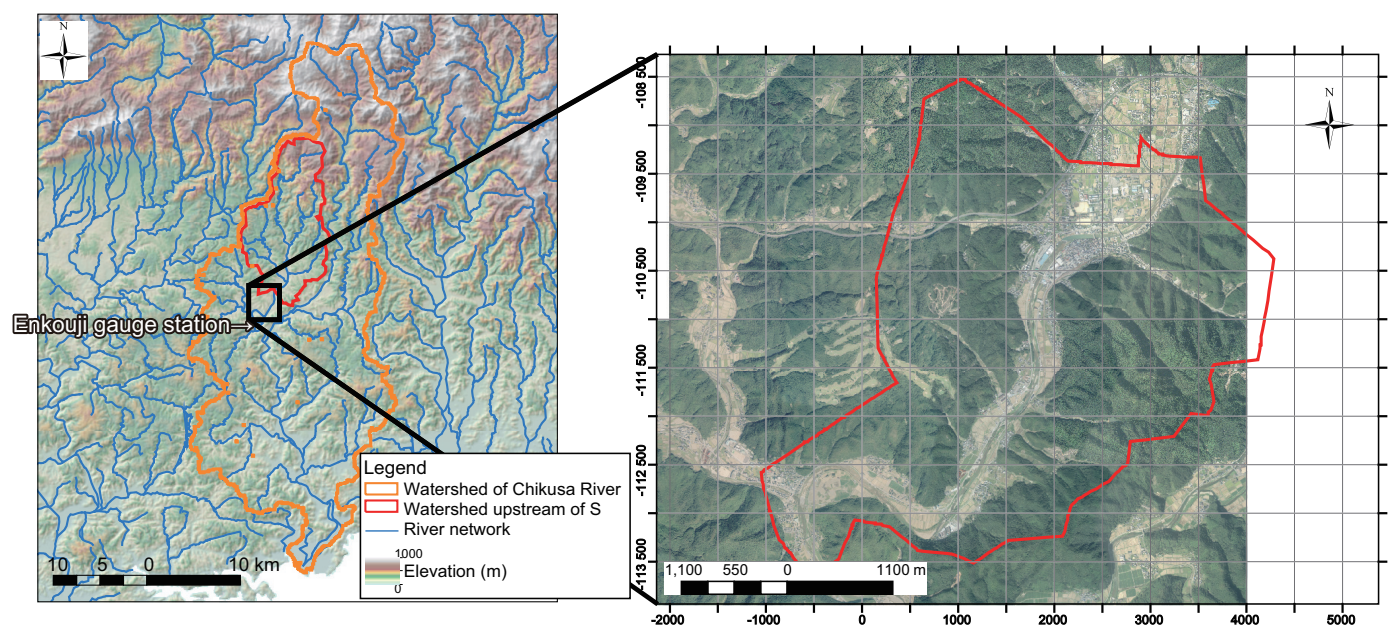

Figure 5. Watershed of Chikusa River (left) and hydraulic flood model domain in section S of Sayo River (right). (Source: National Land Numerical Information download service, Ministry of Land, Infrastructure, Transport and Tourism, Japan, for digital elevation model, watersheds, and river network and Kinki Regional Development Bureau, Ministry of Land, Infrastructure, Transport and Tourism Japan for the aerial photo taken in 2010.)

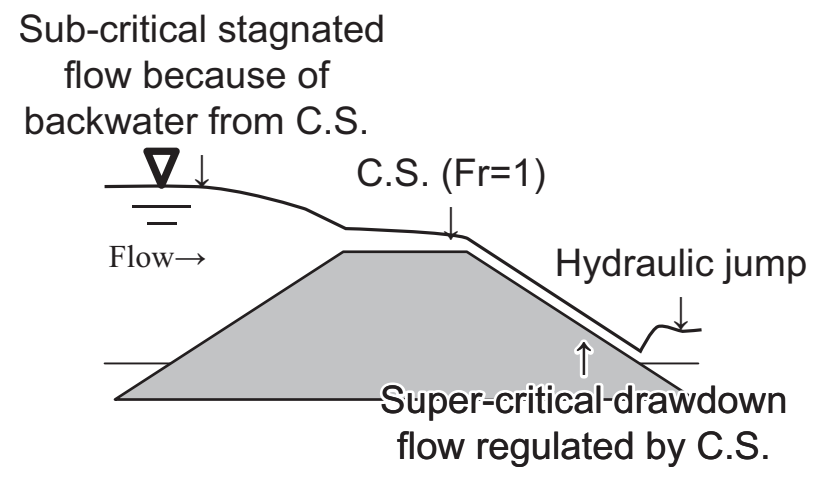

Figure 6. Schematic diagram of one-dimensional flow over embankment. C.S. in figure corresponds to the critical section where the flow is critical.

bankment crest. The flow on the lee side of embankment is supercritical and the water level is regulated by the C.S. The local flow rate over the embankment crest estimated by the embankment-resolving fine-resolution inundation simulation (e.g., Tsubaki and Kawahara, 2013) has non-negligible uncertainty because of high sensitivity to the embankment shape and height represented by the undulation of the calculation grid based on the digital elevation model and land cover data. This is because exchange between kinetic and potential energies is actively occurring in this area (Chow, 1959), leading to a two-dimensionally undulating water surface profile and inhomogeneous velocity distribution (Tsubaki and Kawahara, 2013). For these reasons we use the upstream water level as a hazard level to explain the probability of railway failure.

Accounting for other variables in the design of fragility curves remains a matter of debate. In fact, the time dura- tion of overtopping and turf quality was accounted for to obtain fragility curves for a well-managed river embankment in Apel et al. (2004). Their model parameters were deterministically fitted to the experiment conducted in Hewlett et al. (1987) and the damage probability was not validated to the levee breach records.

Properties of ballast, embankment fill, and surface cover of the embankment are regulated in the construction code and regularly inspected and maintained. The two railway lines focused on in this paper are single-track, unelectrified railways running through mountainous regions, which started operation about 90 years ago. In this regard, the material properties of the railways are relatively homogeneous. However, the remaining uncertainties in properties of the embankment are not negligible when deterministically evaluating failure occurrence. This is true for river embankment overtopping as well, so a probabilistic approach has been used for this problem (e.g., Dawson et al., 2005; Apel et al., 2009).

In the fragility curve approach, a probabilistic damage function can be expressed by a two-parameter normal distribution function (Shinozuka et al., 2000; Suppasri et al., 2012; Mas et al., 2012),

$P(a)=\Phi\left[\frac{a-\mu}{\sigma}\right]$,

or log-normal distribution function,

$P(a)=\Phi\left[\frac{\ln (a / c)}{\zeta}\right]$

where $P()$ represents the conditional probability of occurrence for the specific state of damage; $\Phi$ is the normal error function; $a$ represents the hazard level; $\ln ()$ represents the natural logarithm; $\mu$ and $\sigma$ are the median and standard 

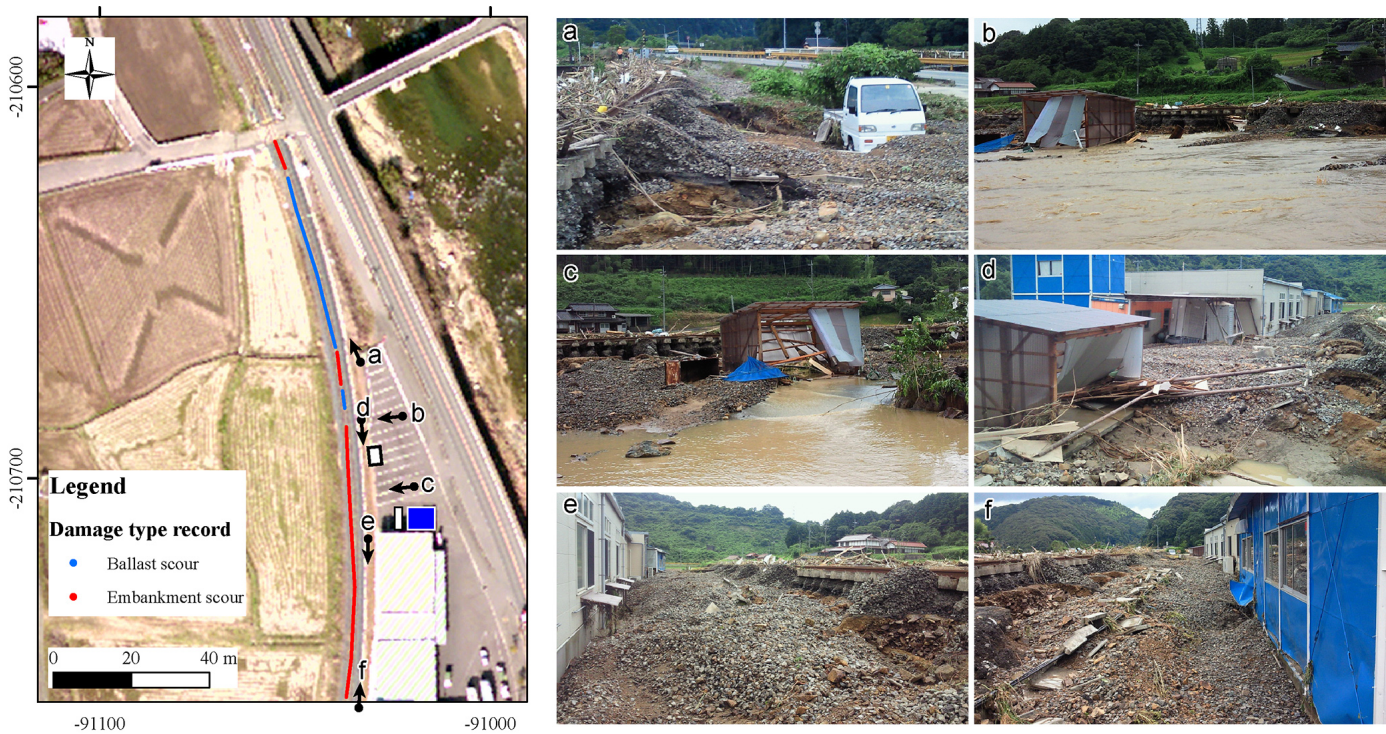

Figure 7. Example of the photos showing the status of the railway ballast-embankment scour just after the flood. Shooting location and direction of each photo are both plotted in the left orthorectified aerial photo taken in February 2012 (photo source: M. Kikunaga).

deviation of hazard level; and $c$ and $\zeta$ are the median and log-standard deviation, respectively (refer to the list of mathematical notation used in this paper at the end of the Appendix). The deviation parameters $\sigma$ or $\zeta$ represent both uncertainty in hazard level $a$ and variation in fragility among data points (Mander, 1999). The estimation of the two model parameters (median and deviation) is carried out by maximizing the likelihood function. The likelihood function for binary damage (damage/no damage) is

$L=\prod_{i=1}^{N}\left[P\left(a_{i}\right)\right]^{x_{i}}\left[1-P\left(a_{i}\right)\right]^{1-x_{i}}$

where $a_{i}$ is the hazard level (overtopping water depth in this study) of sample number $i ; x_{i}=1$ or 0 indicates embankment scour or no breach, respectively, under the corresponding damage type; and $N$ is the total number of samples.

\subsection{Railway damage record}

\subsubsection{Asa River flood of $\mathbf{2 0 1 0}$}

Locations of ballast and embankment fill scour are determined by investigating photos showing the status of the railway ballast-embankment scour just after the flood (see Fig. 7 as an example) and the status after the recovery works (personal communication with the factory and downloaded from the internet) as well as aerial photos of the area obtained in February 2012 and orthorectified to $0.5 \mathrm{~m}$ resolution. The ballast and embankment just after reconstruction differed in color compared with the section not scoured because weathering, iron dust due to railway passage, and vegetation cover alter the surface color.

\subsubsection{Sayo River flood of 2009}

Kaneko (2010) reported ballast and embankment scour damage to the railway as a function of kilometer post along the track and our damage map was mainly based on this report. Additionally, site survey data (I. Ario, personal communication, 2009), photos from the internet, and aerial photos, taken in October 2009 (immediately after the flood) and orthorectified in $0.2 \mathrm{~m}$ resolution, were utilized to detail damage along the length of the section of railway.

\subsection{Estimation of overtopping water stage}

\subsubsection{Hydraulic model for flood flow simulation (Tsubaki et al., 2012a)}

The river and floodplain flows were calculated by solving the shallow water equations. The basic equations solved here are as follows:

$$
\begin{aligned}
& \frac{\partial \boldsymbol{U}}{\partial t}+\frac{\partial \boldsymbol{E}}{\partial x}+\frac{\partial \boldsymbol{F}}{\partial y}=\boldsymbol{S}, \\
& \boldsymbol{U}=\left(\begin{array}{lll}
h & h u & h v
\end{array}\right)^{T}, \\
& \boldsymbol{E}=\left(\begin{array}{lll}
h u & h u^{2}+0.5 g h^{2} & h u v
\end{array}\right)^{T}, \\
& \boldsymbol{F}=\left(\begin{array}{lll}
h v & h u v & h v^{2}+0.5 g h^{2}
\end{array}\right)^{T},
\end{aligned}
$$

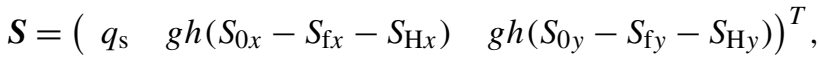

where $t$ is the time, $x$ and $y$ are the horizontal coordinates, $h$ is the water depth, $u$ and $v$ are the depth-averaged velocities in the $x$ and $y$ directions, $g$ is the gravitational acceleration, $q_{\mathrm{S}}$ is the source water mass due to rainfall, and $S_{0 x}$ and $S_{0 y}$ 
are the bed slopes in the $x$ and $y$ directions calculated using the ground elevation $z$ as

$S_{0 x}=-\frac{\partial z}{\partial x}, \quad S_{0 y}=-\frac{\partial z}{\partial y}$.

$S_{\mathrm{f} x}$ and $S_{\mathrm{f} y}$ are the friction slopes evaluated by using the Manning's roughness coefficient $n$ as follows:

$S_{\mathrm{f} x}=\frac{n^{2} u \sqrt{u^{2}+v^{2}}}{h^{4 / 3}}, S_{\mathrm{f} y}=\frac{n^{2} v \sqrt{u^{2}+v^{2}}}{h^{4 / 3}}$.

$S_{\mathrm{H} x}$ and $S_{\mathrm{H} y}$ are the energy slope due to the bridge with piers. These terms are effective only at the cell interface located in the bridge cross section.

$S_{\mathrm{H} x}=\frac{\partial H_{\mathrm{b}}}{\partial x}, S_{\mathrm{H} y}=\frac{\partial H_{\mathrm{b}}}{\partial y}$,

where $H_{\mathrm{b}}$ is the energy head relative to loss due to the bridge. The amount of head loss was calculated by using D'Aubuisson's empirical formula (Chow, 1959; Sakano, 2003; Tsubaki et al., 2012a). The equations were solved by means of the finite volume method on an unstructured triangular grid. The flux difference scheme was used to evaluate fluxes through the boundaries of each triangular cell.

\section{(a) Asa River model}

Due to the short length of the river reach $(2 \mathrm{~km})$ focused on in this study, and the relatively steep riverbed slope $(1 / 240)$, the flood was evaluated using a steady peak flow simulation. The inflow rates, based on the hydrologic analysis described in Sect. 2.1 and validated in Ube Construction Office (2012), were used as constant inflow boundary conditions for a two-dimensional unsteady flow model. Resolution of the triangular mesh was $2 \mathrm{~m}$ in the area of railway embankment fill and $5 \mathrm{~m}$ elsewhere. Manning's $n$ was set to $0.03 \mathrm{~m}^{-1 / 3} \mathrm{~s}$ in the river channel and floodplain (Ube Construction Office, 2012), and $0.1 \mathrm{~m}^{-1 / 3} \mathrm{~s}$ in vegetated and built-up areas (Chow, 1959). This river channel roughness equals that used by Yamaguchi Prefecture in historical analyses (Ube Construction Office, 2012). The downstream boundary condition was water level as determined by Yamaguchi Prefecture's calculation (Ube Construction Office, 2012).

Note that the two-dimensional shallow water model with fine calculation grid was reported to be substantially less sensitive to the roughness coefficient (Horritt, 2000; Horritt and Bates, 2002; Tsubaki and Kawahara, 2013) and the roughness coefficient reflects more physical basis (Horritt and Bates, 2002) compared with the simplified models like the 1-D inundation model (e.g., HEC-RAS) or 1-D river model coupled with a simplified 2-D inundation model (e.g., LISFLOOD-FP).

\section{(b) Sayo River model (Tsubaki et al., 2012a)}

The domain represented in the inundation simulation (Fig. 5, right panel) was about $15 \mathrm{~km}^{2}$ in area. The Sayo River flows through this section, and no major tributaries are present here. Elevation data for the calculation grid were configured using aerial lidar (light detection and ranging) for the riverside region, and a $50 \mathrm{~m}$ grid DEM (digital elevation model) was utilized for the intermountain area. A comparatively small grid size ( $3 \mathrm{~m}$ for the length of a side of a triangle) was used around the river and the railway to represent the details of the topography (Bates et al., 2003; Cobby et al., 2003; Rath and Bajat, 2004). In the mountain area, a larger grid size ( $40 \mathrm{~m}$ in length) was used to reduce computational load. Manning's roughness parameter $\mathrm{n}$ was set to $0.02 \mathrm{~m}^{-1 / 3} \mathrm{~s}$ for the riverbed and the floodplain, $0.1 \mathrm{~m}^{-1 / 3} \mathrm{~s}$ for vegetated areas of the river course and floodplain as well as for residential areas (Chow, 1959), and $0.3 \mathrm{~m}^{-1 / 3} \mathrm{~s}$ for mountainous areas. The river channel roughness was determined based on the bed material size (Chow, 1959, p. 206) and the surface cover status. The area covered by trees in the channel was considered vegetated.

The discharge estimated by using a hydrological model based on ground rain gauge data (Fujita et al., 2014) was used as the inflow boundary condition (Sect. 2.2). The rating curve at the outflow cross section was estimated and the flow rate at the outflow cross section calculated by the hydrological model was converted to water stage. The source term in the mass conservation equation $\left(q_{\mathrm{s}}\right.$ in Eq. 5) represents the direct runoff in this area; the observed gross precipitation is multiplied by a runoff ratio of 0.85 to account for the amount of net surface runoff in this area.

\subsubsection{Validation of inundation flow models}

To validate the inundation flow models, calculated results are compared with inundation records.

\section{(a) Asa River model}

Water levels hindcast by the flood simulation are compared with measured water level traces from two locations depicted in the right panel of Fig. 4. Steady flow boundary conditions were used for model inflow and outflow, though the presence of vortices (circulatory flow) over the floodplain and near the riverbanks caused a complex velocity field and prevented perfectly steady flow from forming (Tsubaki and Kawahara, 2013). Due to these fluctuations, modeled water levels were assessed via both $20 \mathrm{~min}$ running averages representing each minute of model output, as well as maximum water levels during these same intervals. Flood elevation trace no. 1, on the inner wall of the factory, was measured to be $25.98 \mathrm{~m}$ (in Tokyo datum, hereafter). The average modeled flood elevation here was $25.79 \mathrm{~m}$, and the maximum modeled flood elevation at this location was $25.90 \mathrm{~m}$. At location no. 2, 


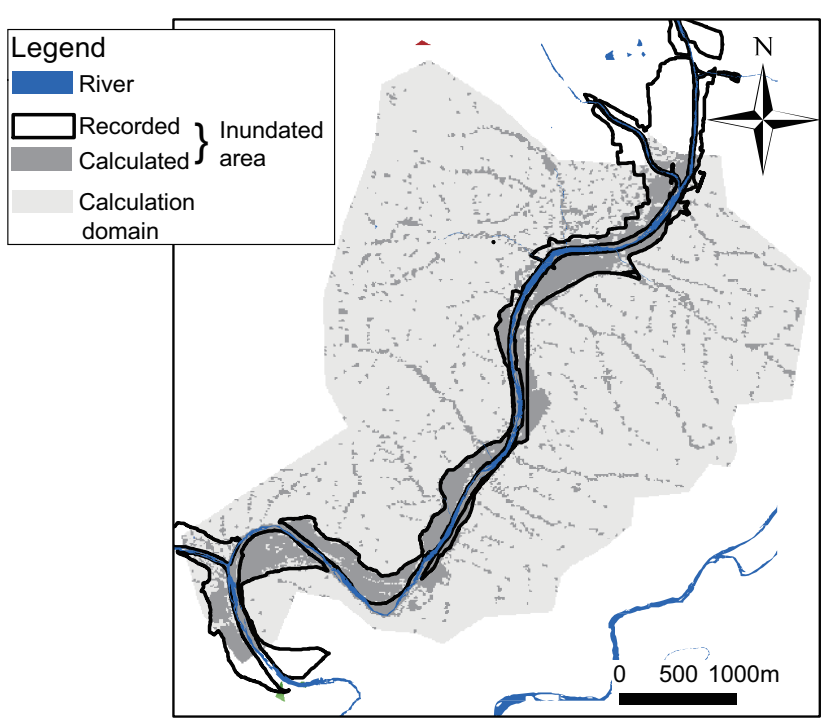

Figure 8. Comparison of calculated and recorded inundation areas (Tsubaki et al., 2012a).

the recorded trace elevation was $25.81 \mathrm{~m}$, model average elevation was $25.61 \mathrm{~m}$, and model maximum elevation was $25.67 \mathrm{~m}$. Modeled average elevation is about $19 \mathrm{~cm}$ too low, and maximum elevation is about $11 \mathrm{~cm}$ too low, compared to measured trace elevations.

\section{(b) Sayo River model}

As shown in Fig. 8, the calculated inundation area corresponds closely to the recorded inundation area based on the field survey conducted by Hyogo Prefecture. In Fig. 9, calculated and recorded inundation water stages are compared. The calculated water stage is represented by $h+z$. The mean absolute error is $0.28 \mathrm{~m}$, and the magnitude of the error is smaller than, but comparable to, the magnitude of inundation water depth, $1 \mathrm{~m}$.

\subsubsection{Uncertainty in flood water stage}

According to the benchmarking of a two-dimensional highresolution ( $\sim 2 \mathrm{~m}$ grid spacing, lidar topography based) urban flood model reported by Hunter et al. (2008), the uncertainty in predicted water level among six hydraulic models was assessed as $0.05 \mathrm{~m}$. This is the same order of RMSE in the terrain data they used and a similar result was reported in Tsubaki and Kawahara (2013), too.

The difference between calculated and recorded water stages in our simulation was $0.1 \sim 0.3 \mathrm{~m}$, and this is larger than the water level uncertainty estimated by numerical models reported by Hunter et al. (2008). This discrepancy may be related to larger inaccuracy in the lidar data we used due to very uneven terrain and quite a complex surface cover, including rails on the railway embankment and vegetation

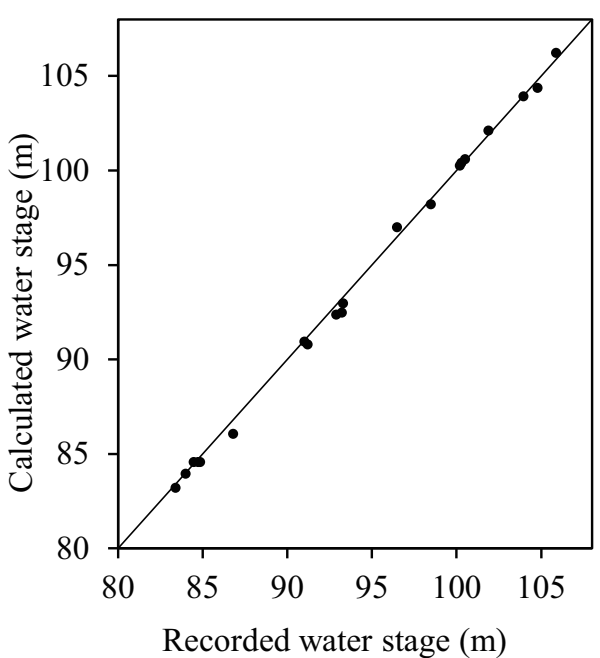

Figure 9. Comparison of calculated and recorded flood stages in Tokyo datum. The straight line shows the perfect-agreement line, i.e., recorded water stage $=$ calculated water stage (Tsubaki et al., 2012a).

cover on the embankment slope. Moreover, there is a difference in the definitions of calculated and recorded water depths, namely the calculated water depth is a cell-averaged quantity but the recorded water depth denotes the local water depth around obstacles; this caused an underestimation of the calculated water depth as reported in Sect. 3.3.2a for the Asa River and shown in Fig. 9 for the Sayo River.

In summary, the magnitude of uncertainty in flood water stage in this study was non-negligible but inevitable in practice because of the complexity of the topography and uncertainty in the topographic data available. The fragility curve concept can account for the uncertainty in the explanatory variable, overtopping water depth in this study. The effect of uncertainty in water level prediction on the fragility curve will be discussed in Sect. 5.3.

\section{Results}

The difference between $H$ and the elevation $z$ of the railway track is overtopping water depth $\Delta h$, namely $H=z+\Delta h$, and $\Delta h$ was correlated with the recorded types of damage categorized into "no damage", "ballast scour", and "embankment scour" in Sect. 3.2, and listed in Tables A2 and A3. Then, fragility curves were developed based on this correlation. Both upstream water level $H$ and rail track elevation $z$ are derived from the cell-averaged quantities used in the model described in Sect. 3.3.

The elevation of water overtopping the rail tracks was taken as water surface elevation $H$ averaged over a $2 \mathrm{~m}$ diameter area at a distance of $5 \mathrm{~m}$ from the center line of the tracks. For the generation of fragility curves "no damage" with no overtopping $(\Delta h \leq 0)$ does not directly con- 


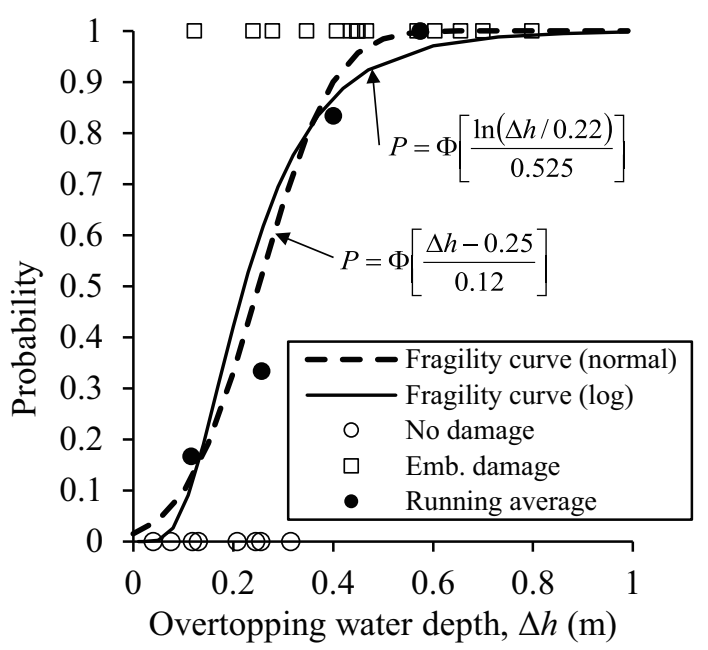

Figure 10. Fragility curves for embankment scour damage described by normal and log-normal distributions.

tribute to determining the coefficients in Eqs. (1) or (2) so the point where neither overtopping was observed nor track damage was recorded was excluded. The locations were selected where the model result showed that the tracks were indeed overtopped and the damage types were confidently observed in Sect. 3.2. As such, 10 data points were selected for the Asa River, and 21 data points for the Sayo River. These 31 data points, at which damage type was described in Sect. 3.2 and the overtopping water depth was estimated in Sect. 3.3, were used as samples to fix parameters in the fragility curves (Eqs. 1, 2).

Figure 10 displays the fragility curves for the embankment scour using the normal distribution (depicted by the dashed line with $\log$-likelihood $\ln (L)=-7.3$ ) and the log-normal distribution (the solid line with log-likelihood $=-7.9$ ) resulting from data points at which either no damage (the number of samples was $n=8)$ or embankment scour $(n=16)$ was observed at two flood events. In Fig. 10, open symbols represent individual data points, while filled figures represent overtopping water depth and damage data which have been put through a five-point running average after ordering by overtopping water depth. Though both normal and lognormal distribution models (solid and dashed lines, respectively) represent well the trend of damage probability based on the field record (filled circles), the normal distribution has a slightly better fit.

Figure 11 shows the fragility curves for the ballast scour using the normal distribution (depicted by the dashed line with log-likelihood $=-2.6$ ) and the log-normal distribution (the solid line with log-likelihood $=-2.6$ ) resulting from data points at which either no damage (the number of samples was $n=8$ ) or ballast scour ( $n=7$ ) were observed during the two flood events. The normal and log-normal curves were almost identical.

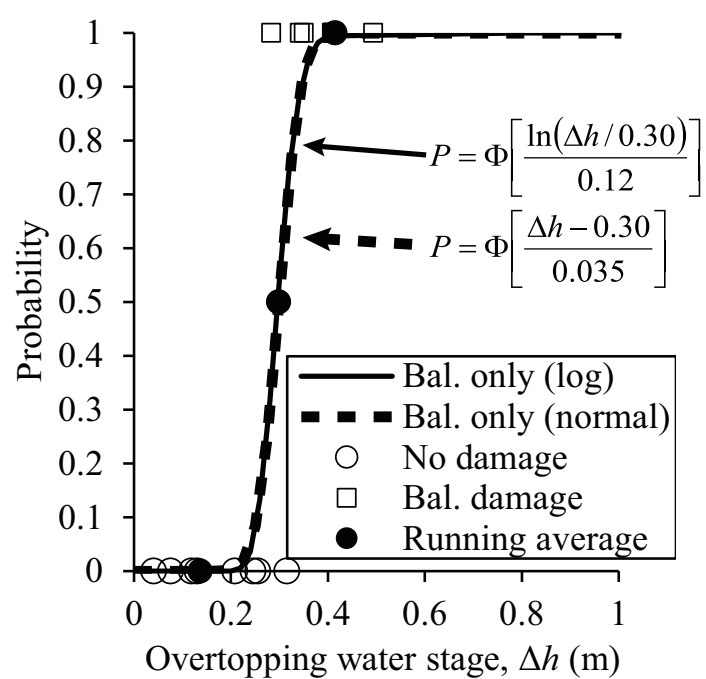

Figure 11. Fragility curves for ballast scour damage described by normal and log-normal distributions.

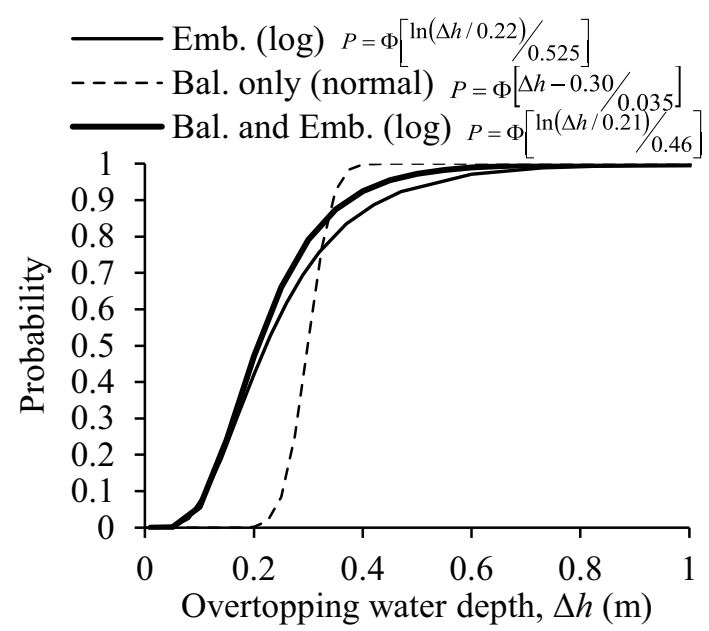

Figure 12. Fragility curves for ballast scour (Bal. only), embankment scour (Emb.), and ballast and embankment scour (Bal. and Emb.)

Figure 12 compares the normal fragility curve for ballast scour (dashed line) and a log-normal curve for the combination of ballast scour and embankment scour (thick line, loglikelihood $=-8.9$ ). The fragility curve for ballast scour has a larger mean and smaller standard deviation compared with the curve for embankment scour and the curve for combined ballast scour and embankment scour. The damage probability at medium overtopping water depth $0.2 \mathrm{~m}<\Delta h<0.6 \mathrm{~m}$ for the combined ballast and embankment scour is slightly larger than the probability for embankment scour only. 


\section{Discussion}

\subsection{Consistency in lower limit of damage probability with experimental result}

Ballast damage is a transitional type of damage, falling between "no damage" and embankment fill scour in its severity. The number of samples with ballast damage available in this study is limited ( $n=7$ ) because this type of damage occurred in between sections with embankment fill scour and "no damage". During a full-scale experiment of ballast scour (Tsubaki et al., 2012b), steady scour was observed beginning at a flow rate per unit length of $q_{\mathrm{c}}=0.045 \mathrm{~m}^{2} \mathrm{~s}^{-1}$. Figures 10-12 show overtopping water depth on the $x$ axis, but there is a relation between surcharge water depth and overtopping flow rate as described previously. By adopting the broad-crested weir concept, the overtopping discharge per unit length can be estimated as

$q=\alpha \Delta h^{3 / 2}$,

where $\alpha=2.46$ to 3.47 and $\Delta h$ is the overtopping water depth (Chow, 1959). Using Eq. (9) and $\alpha=2.46$, the overtopping water depth is converted to the overtopping flow rate per unit length in Fig. 13. In this figure, the critical flow rate for ballast scour is depicted as a vertical dashed line. This critical flow rate corresponds well to the initial rise of the log-normal fragility curve for embankment and ballast scour. The agreement of the initial rise of the fragility curve of embankment-ballast scour and critical flow rate to initiate ballast scour indicates that railway overtopping damage begins with ballast scour and progresses to embankment scour. This also implies that the critical flow rate for initiation of ballast scour based on the full-scale experiment of ballast scouring conducted by Tsubaki et al. (2012b) can be used as a critical condition for initiation of railway ballast damage in the field. The initial rise of the fragility curve of ballast scour had substantially large flow rate compared with the critical flow rate based on the ballast scour experiment. This implies the fragility curves of ballast scour underestimate the damage probability.

\subsection{Profile of upper side of fragility curves}

The largest overtopping flow rate at which no damage was observed at the point $\mathrm{s} 1$ (Table A2, $\Delta h=0.31 \mathrm{~m}$ and $q=$ $0.43 \mathrm{~m}^{2} \mathrm{~s}^{-1}$ ) and damage probability for this hazard level was $0.6-0.8$ for all developed fragility curves (Figs. 13, 9, $10,11,12)$. The damage probabilities converge to unity for larger hazard level and convergent rate with increase of hazard level differs depending on the types of fragility curve. The fastest convergence of the damage probability to unity was observed in the ballast scour model and followed by the ballast and embankment scour model. The embankment scour model showed the slowest convergence to unity. The log-normal models also showed relatively slow convergence

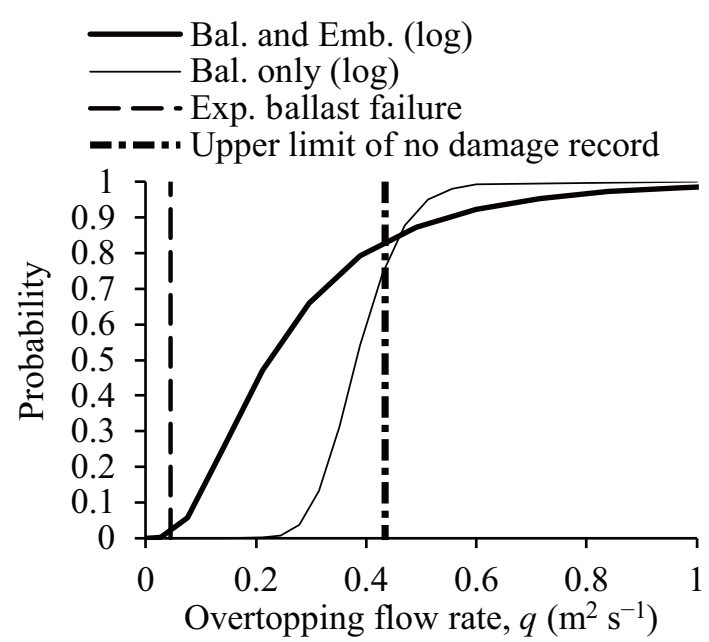

Figure 13. Fragility curve for ballast failure using overtopping flow rate per unit length. The dashed line indicates the experimental bound at which the onset of ballast scour occurs (Tsubaki et al., $2012 b$ ). The double line corresponds to the upper limit of the flow condition where no damage was observed.

to unity compared with the corresponding normal models. An overtopping flow rate of $0.5 \mathrm{~m}^{2} \mathrm{~s}^{-1}$ (corresponding to an overtopping water depth of $0.4 \mathrm{~m}$ ) is quite an intense flow from the viewpoint of earthen embankment overtopping (Apel et al., 2004) and it is very unlikely that no scour will occur during such an intense flow. The damage probability of the ballast scour model was almost unity but the damage probability of the embankment scour model and embankment and ballast scour model was about 0.9 and 0.95 for this range $\left(q=0.5 \mathrm{~m}^{2} \mathrm{~s}^{-1}\right.$ and $\left.\Delta h=0.4 \mathrm{~m}\right)$. Thus, the log-normal models and the embankment scour models may underestimate the damage probability for large hazard level.

\subsection{On the deviation of probabilities}

In Fig. 11, the fragility curve for ballast scour has a median overtopping water depth of $\Delta h=0.30 \mathrm{~m}$, and its variance $\sigma=0.035 \mathrm{~m}$ is smaller than those of the fragility curves for the embankment scour and combined ballast and embankment scour. It must be kept in mind that the lidar topography used in the flood model has an RMSE on the order of $0.1 \mathrm{~m}$, and the uncertainty in hindcast flood levels was on the order of $0.2 \mathrm{~m}$, so the standard deviation $\sigma=0.035 \mathrm{~m}$ of the ballast scour model is very small compared with expected uncertainty in the estimated overtopping water level. The experiment of Tsubaki et al. (2012b) showed ballast scour to begin at $q_{\mathrm{c}}=0.045 \mathrm{~m}^{2} \mathrm{~s}^{-1}$, which is an order of magnitude smaller than the median $\left(q=0.4 \mathrm{~m}^{2} \mathrm{~s}^{-1}\right)$ or lower limit $(q=$ $\left.0.25 \mathrm{~m}^{2} \mathrm{~s}^{-1}\right)$ of the fragility curve for ballast scour shown in Fig. 13. Therefore, it appears the calculated fragility curve for ballast scour in this study may overestimate the condition experimentally evaluated in Tsubaki et al. (2012b). This 

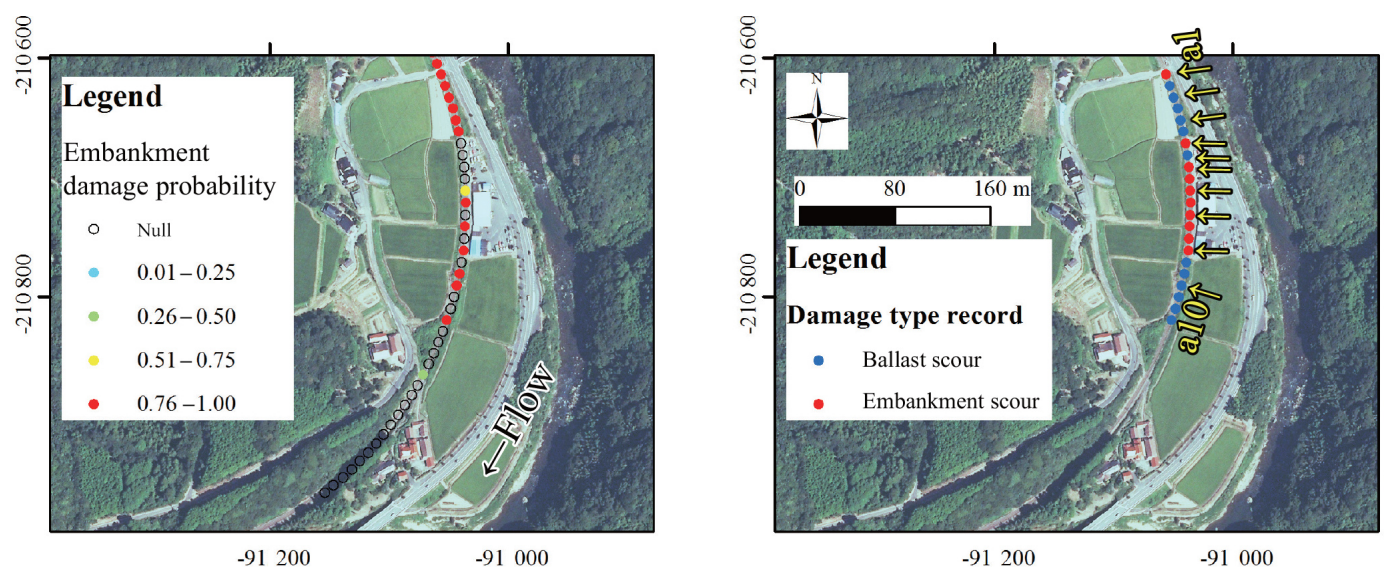

Figure 14. Estimated damage probability (left) and damage type record (right) at Asa River section M. The yellow symbols in the right map depict data points listed in Table A1.

may partially be explained by the fact that the ballast embankment in the field had been consolidated due to periodical loading by railcars so the actual ballast may have greater resiliency than in the experiment conducted by Tsubaki et al. (2012b). Even so, ballast should be more vulnerable to overtopping scour than embankment fill is, but the fragility curves shown in Fig. 13 did not correspond to such a relation. It is also possible that, in the field cases studied, ballast scour at smaller overtopping flow rates always coincided with combined ballast and embankment scour, not ballast scour alone. The fragility curve for ballast and embankment scour is the most feasible among the fragility curves developed in this study. Future work is needed to improve the fragility curve for ballast scour by acquiring more sample data points in the field and running further hydraulic experiments.

\subsection{Validation of railway fragility curve}

A validation of the combined damage fragility curve, of which feasibility was discussed above, was conducted by comparing its calculated probabilities to the actual damage record. The normal distribution for combined ballast and embankment scour was determined to be the most feasible model based on the discussion in Sects. 5.1-5.3. Via the model, the damage probability along the rail track in the Asa River floodplain at $10 \mathrm{~m}$ intervals was calculated and plotted in Fig. 14 (left). Thirty-one of the data points, used in Sect. 4 and listed in Tables A1 and A2 to obtain the fragility curves, were selected where the damage type record was confident (e.g., not marginally at the border of two damage types), but a point array at $10 \mathrm{~m}$ intervals was used for the validation here. Damage probability in Fig. 14 (left) is calculated without regard to the types of failure (ballast or embankment scour), but it is calculated with the fragility curve for ballast and embankment scour; however, the actual damage record of the right figure distinguishes the type of damage. In Fig. 14, there is variability in the calculated result, but the area where the ballast and embankment scours were observed is predicted as a high damage probability area. The points at which no damage was calculated are points at which the flood model calculated either a very shallow overtopping water depth, or no overtopping at all. The railway crest in this section is almost horizontal. Since the crest of the railway embankment consists of both rail and railway ties (sleepers), the $1 \mathrm{~m}^{2}$ resolution lidar data cannot resolve this, and the $1.7 \mathrm{~m}^{2}$ triangular mesh carries forward this variation, leading to an unavoidable difference between modeled and actual topography. Since actual railway crest elevation does not experience spurious variations at $10 \mathrm{~m}$ intervals, topography based on lidar data of limited resolution and accuracy might be improved by application of a spatial filter along the railway.

Figure 15 shows calculated and observed damage to the railway along the Sayo River. The domain is decomposed into two segments (A and B) in the discussion below. Continuous damage was recorded along a portion of Segment A, and this damage was reproduced well in the fragility curve calculation. In this segment, damage occurred in locations at which relatively steep slopes existed in the railway crest elevation profile (Fig. 16). Since the locations of railway embankment overtopping were governed by a longitudinal slope of the railway and large-scale topography in this segment A, the flood model was able to simulate actual overtopping location and flow rate with higher accuracy, and damage probability resulting from the fragility curve matched recorded damage well. In Segment B, estimated damage probability was high at points that experienced actual damage, but many other points estimated to have high damage probability experienced no actual damage. In regions such as this, where spatially sporadic damage is calculated, fragility curves are still useful for predicting whether damage will occur, but they cannot predict the specific locations at which the damage should be expected. In this segment, elevation of the railway embankment crest was very smooth, with no steep slopes in 

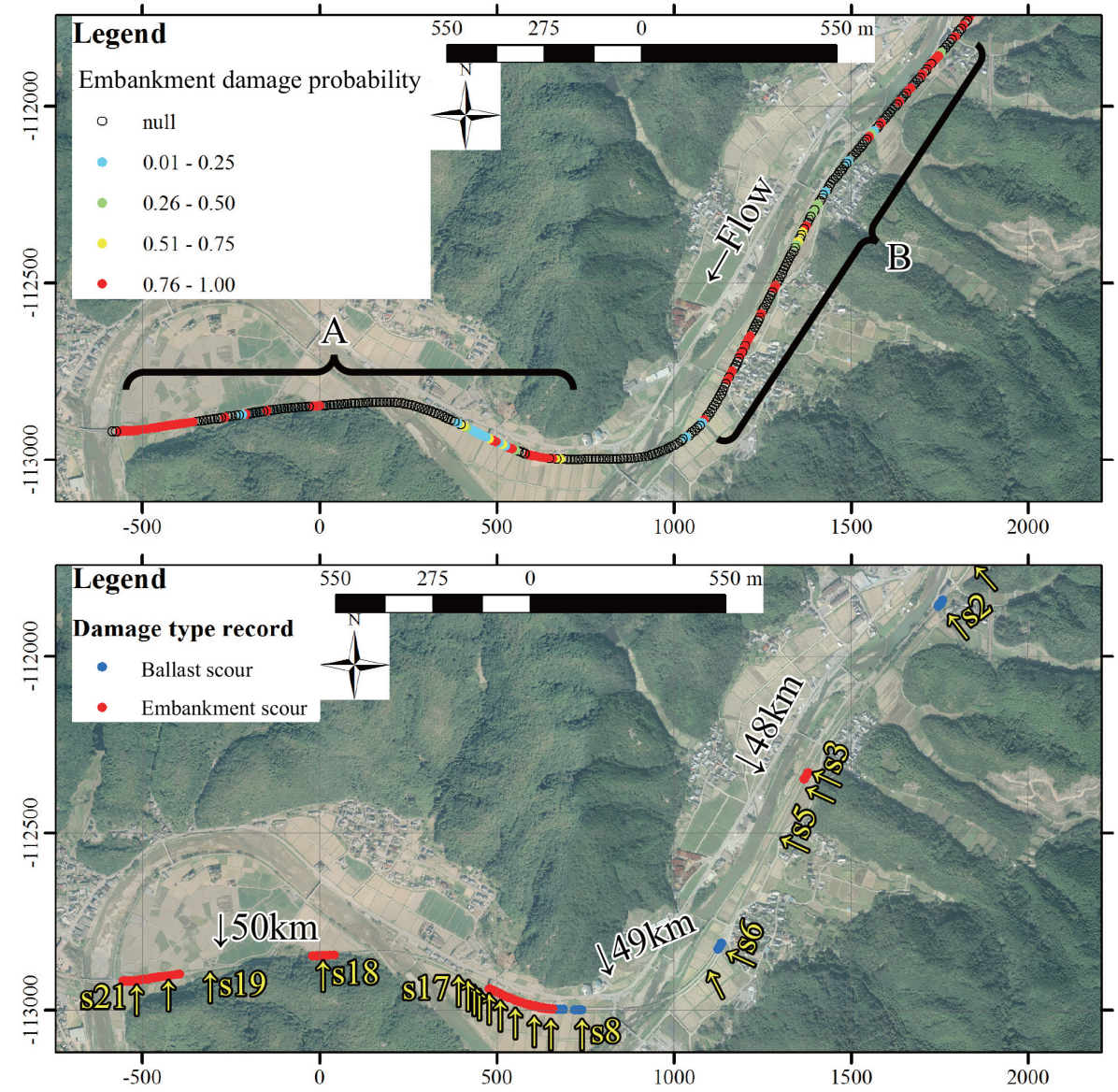

Figure 15. Estimated damage probability (top) and damage type record (bottom) at Sayo River section S. The yellow symbols in the bottom figure depict data points listed in Table A2. (Source: Kinki Regional Development Bureau, Ministry of Land, Infrastructure, Transport and Tourism Japan for the aerial photo taken in 2010.)

crest elevation (Fig. 16). Therefore, the entire segment was overtopped with shallow surcharge. However, small errors in topography at the size of each model grid cell caused large difference in the overtopping water depth, resulting in erroneous damage probabilities at the $10 \mathrm{~m}$ intervals at which damage was assessed. The fragility curve concept can also account for uncertainty in hazard level (overtopping water depth in this paper) by adjusting the deviation parameters $\sigma$ or $\zeta$ in Eq. (1) or (2) (Mander, 1999); in segments within which sporadic damage is predicted, the level of damage can be estimated by averaging the damage predicted for points within the segment. However, the reason damage in Segment B of Fig. 15 was not evaluated as such an average is that the error in grid-scale model topography was too large to just cause variations in overtopping water depth; rather, the error caused many points within the segment to not experience any overtopping at all. Therefore, the model predicted scattered damage for Segment B.

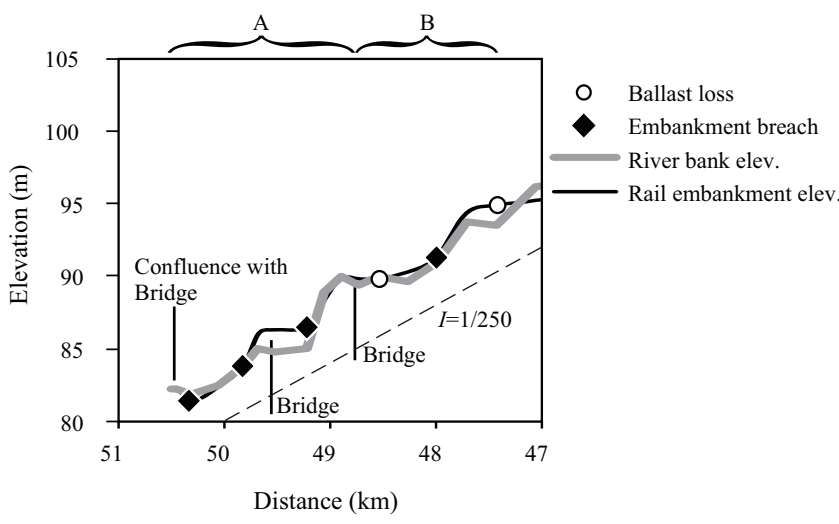

Figure 16. Longitudinal profiles of railway and riverbank elevation. The cross sections where the river and railway intersect are indicated as "bridge" (Tsubaki et al., 2012a). 


\section{Conclusions}

This paper shows the significance of evaluating the likelihood of damage to railway embankments due to overtopping. Fragility curves were developed to relate damage probability to overtopping water depth, itself calculated via the use of a hydraulic flood model. Fragility curves were generated based on recorded observations of railway damage types, simulated overtopping water depth and two types of curves (normal and log-normal distributions). Each fragility curve was validated by comparison between modeled damage probability and records of observed damage. The fragility curve for ballast scour, the damage type expected to be the initial phase to lead the embankment scour, did not match the criteria revealed through laboratory experiments of ballast scour and may underestimate actual damage probability. However, the fragility curve for combined ballast and embankment scour represents well the laboratory experiment result for the onset of scour. Field validation of the combined damage fragility curve was carried out by comparing modeled damage probability with recorded damage at two different river sections. At one location, where recorded damage indicated continuous railway washout over stretches, fragility curve damage probability agreed with observed damage quite well. In contrast, the model did not represent well-observed damage in locations of relatively flat and level railway crest, where variations in the simulated overtopping water depth were affected by small errors in the topographic data, resulting in sporadic flood overtopping where no damage existed in reality.
Though the fragility curves developed here are useful for estimation of damage probability for single-track nonelectrified railway embankments, the limited number of data points used to generate these curves could prevent them from being applicable to a variety of situations. To make these curves more robust, more field records in different types of environments are needed. Furthermore, the fit of modeled ballast scour probability to observed ballast damage was unsatisfactory, indicating the necessity for further laboratory experiments and field data collection. Whether the developed fragility curves is applicable to railway embankments outside Japan will depend on how closely construction/maintenance standards in the country of application matches the construction standards in Japan. In addition, the role of small errors in the hydraulic flood model result on predicted damage probability has become clear, and the application of spatial filtering to improve model accuracy needs to be investigated in the future.

\section{Data availability}

The collected and processed field data are available from the corresponding author. More details about meteorological, hydrological and hydraulic assessment for Asa River flood and Sayo River flood are available on doi:10.2208/jscejhe.70.I_1441 (Tsubaki et al., 2014, in Japanese) and https://ir.lib.hiroshima-u.ac.jp/files/public/3/ 39096/20160212131039699174/JHHE_30-1_87.pdf (Tsubaki et al., 2012a), respectively. 


\section{Appendix A: Point-wise data used to develop fragility} curves

Table A1. Point-wise estimated overtopping water depth $\Delta h$ and damage types for the Asa River flood. In damage types row, emb. is embankment scour, bal. is ballast scour, and no is no damage. Location of each point is indicated in Fig. 14.

\begin{tabular}{lrrrl}
\hline Point & Calc $z(\mathrm{~m})$ & Calc $H(\mathrm{~m})$ & $\Delta h(\mathrm{~m})$ & Damage types \\
\hline a1 & 26.89 & 27.36 & 0.47 & emb. \\
a2 & 26.94 & 27.35 & 0.41 & bal. \\
a3 & 26.94 & 27.35 & 0.41 & bal. \\
a4 & 26.90 & 27.35 & 0.45 & emb. \\
a5 & 26.99 & 27.34 & 0.35 & bal. \\
a6 & 27.00 & 27.35 & 0.35 & emb. \\
a7 & 26.94 & 27.35 & 0.41 & emb. \\
a8 & 26.90 & 27.35 & 0.45 & emb. \\
a9 & 26.91 & 27.35 & 0.44 & emb. \\
a10 & 26.93 & 27.34 & 0.41 & bal. \\
\hline
\end{tabular}

Table A2. Point-wise estimated overtopping water depth $\Delta h$ and damage types for the Sayo River flood. Location of each point is indicated in Fig. 15.

\begin{tabular}{lrrrl}
\hline Point & Calc $z(\mathrm{~m})$ & Calc $H(\mathrm{~m})$ & $\Delta h(\mathrm{~m})$ & Damage types \\
\hline s1 & 95.56 & 95.88 & 0.31 & no \\
s2 & 94.96 & 95.30 & 0.34 & bal. \\
s3 & 91.55 & 91.83 & 0.28 & emb. \\
s4 & 91.12 & 91.36 & 0.24 & emb. \\
s5 & 90.85 & 90.98 & 0.13 & no \\
s6 & 89.88 & 90.37 & 0.49 & bal. \\
s7 & 89.85 & 90.10 & 0.25 & no \\
s8 & 87.65 & 87.93 & 0.28 & bal. \\
s9 & 87.37 & 87.94 & 0.57 & emb. \\
s10 & 85.82 & 87.27 & 1.46 & emb. \\
s11 & 86.04 & 87.35 & 1.31 & emb. \\
s12 & 86.52 & 87.31 & 0.80 & emb. \\
s13 & 86.36 & 86.48 & 0.12 & emb. \\
s14 & 86.17 & 86.21 & 0.04 & no \\
s15 & 86.24 & 86.31 & 0.08 & no \\
s16 & 86.16 & 86.27 & 0.12 & no \\
s17 & 82.34 & 82.55 & 0.21 & no \\
s18 & 81.87 & 82.57 & 0.70 & emb. \\
s19 & 82.31 & 82.55 & 0.25 & no \\
s20 & 81.91 & 82.57 & 0.66 & emb. \\
s21 & 81.96 & 82.56 & 0.60 & emb. \\
\hline
\end{tabular}


$a \quad$ hazard level and overtopping water depth $\Delta h$ in this study $(\mathrm{m})$

$c \quad$ median of hazard level $a(\mathrm{~m})$

$g \quad$ gravity acceleration $\left(\mathrm{m} \mathrm{s}^{-2}\right)$

$h \quad$ water depth $(\mathrm{m})$

$H \quad$ water level (m)

$H_{\mathrm{b}} \quad$ energy head relative to bridge energy loss (m)

i slope (-)

$L \quad$ likelihood function (-)

$n \quad$ Manning's roughness coefficient $\left(\mathrm{m}^{-1 / 3} \mathrm{~s}\right)$

$P(a) \quad$ probability of occurrence for the specific state of damage under the condition of $a(-)$

$r \quad$ rainfall intensity $\left(\mathrm{mm} \mathrm{h}^{-1}\right)$

$R_{\mathrm{sa}} \quad$ saturation criterion to start run (mm)

$q \quad$ discharge per unit width $\left(\mathrm{m}^{2} \mathrm{~s}^{-1}\right)$

$q_{\mathrm{s}} \quad$ source in water mass representing precipitation $\left(\mathrm{m} \mathrm{s}^{-1}\right)$

$S_{0_{x}}, S_{0_{y}} \quad$ bed slopes in $x$ and $y$ directions (-)

$S_{\mathrm{f} x}, S_{\mathrm{f} y} \quad$ friction slopes in $x$ and $y$ directions (-)

$S_{\mathrm{H} x}, S_{\mathrm{H} y} \quad$ energy slopes in $x$ and $y$ directions due to the head loss by the bridge pier (-)

$t \quad$ time (s)

$u, v \quad$ depth-averaged velocity components correspond to $x$ and $y$ coordinates $\left(\mathrm{ms}^{-1}\right)$

$x, y \quad$ horizontal coordinates (m)

$\Delta h \quad$ overtopping water depth (m)

$\alpha$ coefficient used to correlate overtopping water depth and flow rate $\left(\mathrm{m}^{1 / 2} \mathrm{~s}^{-1}\right)$

$\mu \quad$ median of hazard level $a(\mathrm{~m})$

$\sigma \quad$ standard deviation of hazard level $a(\mathrm{~m})$

$\Phi \quad$ normal error function

$\zeta \quad \log$-standard deviation of hazard level $a(-)$ 
Acknowledgements. The authors thank Martin Judd at New Jersey Transit for providing us information about railway system damage due to storm surge, Seth Guikema at the University of Michigan for providing us information about HAZUS, Koji Asai at Yamaguchi University, Akihiko Nakamura and Kentaro Tomura at Asia Air Survey Co., Ltd., and Hiroyuki Nagano at National Institute of Technology, Gunma College, for their corporation in the Asa River flood study. Ube construction office, Yamaguchi Prefecture, provided essential data regarding the Asa River flood. Our study was partially funded by the JSPS-NSF Cooperative Program for Interdisciplinary Joint Research Projects in Hazards and Disasters project entitled "Evolution of Urban Regions in Response to Recurring Disasters", a grant from the Chugoku Civil Engineering Foundation for Mutual Aid, Japan, and a grant from the Foundation for River and Watershed Environment Management, Japan.

Edited by: B. D. Malamud

Reviewed by: two anonymous referees

\section{References}

Apel, H., Thieken, A. H., Merz, B., and Blöschl, G.: Flood risk assessment and associated uncertainty, Nat. Hazards Earth Syst. Sci., 4, 295-308, doi:10.5194/nhess-4-295-2004, 2004.

Apel, H., Merz, B., and Thieken, A.: Influence of dike breaches on flood frequency estimation, Comput. Geosci., 35, 907-923, doi:10.1016/j.cageo.2007.11.003, 2009.

Argyroudis, S. and Kaynia, A. M.: Fragility Functions of Highway and Railway Infrastructure, Springer Netherlands, Dordrecht, 299-326, doi:10.1007/978-94-007-7872-6_10, 2014.

Bates, P. D., Marks, K. J., and Horritt, M. S.: Optimal use of highresolution topographic data in flood inundation models, Hydrol. Process., 17, 537-557, doi:10.1002/hyp.1113, 2003.

Brammer, H.: Floods in Bangladesh: II. Flood Mitigation and Environmental Aspects, Geogr. J., 156, 158-165, 1990.

Bunya, S., Dietrich, J. C., Westerink, J. J., Ebersole, B. A., Smith, J. M., Atkinson, J. H., Jensen, R., Resio, D. T., Luettich, R. A., Dawson, C., Cardone, V. J., Cox, A. T., Powell, M. D., Westerink, H. J., and Roberts, H. J.: A High-Resolution Coupled Riverine Flow, Tide, Wind, Wind Wave, and Storm Surge Model for Southern Louisiana and Mississippi. Part I: Model Development and Validation, Mon. Weather Rev., 138, 345-377, doi:10.1175/2009MWR2906.1, 2010.

Cabinet Office, Government of Japan: White paper on elderly society, Cabinet Office, Government of Japan, 2016 (in Japanese).

Changnon, S. A.: Impacts of the 2008 floods on railroads in Illinois and adjacent states, Transactions of the Illinois State Academy of Science, 102, 181-191, 2009.

Chow, V. T.: Open channel hydraulics, McGraw-Hill Book Company, Inc; New York, reprinted by Blackburn Press, 1959.

Cobby, D. M., Mason, D. C., Horritt, M. S., and Bates, P. D.: Twodimensional hydraulic flood modelling using a finite-element mesh decomposed according to vegetation and topographic features derived from airborne scanning laser altimetry, Hydrol. Process., 17, 1979-2000, doi:10.1002/hyp.1201, 2003.

Dawson, D., Shaw, J., and Gehrels, W. R.: Sea-level rise impacts on transport infrastructure: The notorious case of the coastal railway line at Dawlish, England, J. Transp. Geogr., 51, 97-109, doi:10.1016/j.jtrangeo.2015.11.009, 2016.
Dawson, R., Hall, J., Sayers, P., Bates, P., and Rosu, C.: Samplingbased flood risk analysis for fluvial dike systems, Stoch. Env. Res. Risk A., 19, 388-402, 2005.

Federal Emergency Management Agency: Earthquake model, Hazus(R)-MH MR5 technical manual, Federal Emergency Management Agency, Washington, D.C., USA, 2010a.

Federal Emergency Management Agency: Flood model, Hazus(R)MH MR5 technical manual, Federal Emergency Management Agency, Washington, D.C., USA, 2010b.

Federal Emergency Management Agency: Hurricane model, Hazus(R)-MH MR5 technical manual, Federal Emergency Management Agency, Washington, D.C., USA, 2010c.

Fujita, I., Ito, T., and Sayama, T.: Inundation analysis of the 2009 Chikusa River flood and comparison of evacuation criteria, Journal of Flood Risk Management, 7, 54-64, doi:10.1111/jfr3.12020, 2014

Hall, J. W., Dawson, R. J., Sayers, P. B., Rosu, C., Chatterton, J. B., and Deakin, R.: A methodology for national-scale flood risk assessment, P. I. Civil Eng.-Water, 156, 235-247, doi:10.1680/wame.2003.156.3.235, 2003.

Hata, Y., Sakai, H., Shizuma, T., Nozu, A., Ichii, K., and Maruyama, Y.: Evaluation of fragility curve on traffic function of river dike based on strong motion estimation considering empirical site amplification and phase effects - The case of the Natuse River dike for the past large scale earthquakes -, Journal of Japan Society of Civil Engineers, Ser. A1 (Structural Engineering \& Earthquake Engineering (SE/EE)), 71, I_894-I_914, doi:10.2208/jscejseee.71.I_894, 2015 (in Japanese).

Hewlett, H., Boorman, L. A., and Bramley, L.: Design of reinforced grass waterways, Construction Industry Research and Information Association, London, UK, 1987.

Hong, L., Ouyang, M., Peeta, S., He, X., and Yan, Y.: Vulnerability assessment and mitigation for the Chinese railway system under floods, Reliab. Eng. Syst. Safe., 137, 58-68, doi:10.1016/j.ress.2014.12.013, 2015.

Horritt, M. S.: Calibration of a two-dimensional finite element flood flow model using satellite radar imagery, Water Resour. Res., 36, 3279-3291, doi:10.1029/2000WR900206, 2000.

Horritt, M. S. and Bates, P. D.: Evaluation of 1D and 2D numerical models for predicting river flood inundation, J. Hydrol., 268, 8799, doi:10.1016/S0022-1694(02)00121-X, 2002.

Hunter, N. M., Bates, P. D., Neelz, S., Pender, G., Villanueva, I., Wright, N. G., Liang, D., Falconer, R. A., Lin, B., Waller, S., Crossley, A. J., and Mason, D. C.: Benchmarking 2D hydraulic models for urban flooding, P. I. Civil Eng.-Wat. M., 161, 13-30, 2008.

Ichii, K.: A seismic risk assessment procedure for gravity type quay walls, Structural engineering/Earthquake engineering, 19, 131s140s, doi:10.2208/jsceseee.19.131s, 2002.

IPCC: Climate Change 2014: Synthesis Report, Contribution of Working Groups I, II and III to the Fifth Assessment Report of the Intergovernmental Panel on Climate Change, edited by: Core Writing Team, Pachauri, R. K., and Meyer, L. A., IPCC, Geneva, Switzerland, 151 pp., 2014.

Japan Railway Civil Engineering Association: Yearly summary of railway damages, Journal of Japan Railway Civil Engineering Association, 6, 2000-2011 (in Japanese).

Kaneko, Y.: The damages to the railway of the Kishin line between Kyutoku station to Mimasakadoi station due to the typhoon Etau, 
Journal of Japan Railway Civil Engineering Association, 6, 450451, 2010 (in Japanese).

Mander, J. B.: Fragility curve development for assessing the seismic vulnerability of highway bridges, Multidisciplinary Center for Earthquake Engineering Research (MCEER), University at Buffalo, State University of New York, New York, USA, 1999.

Mas, E., Koshimura, S., Suppasri, A., Matsuoka, M., Matsuyama, M., Yoshii, T., Jimenez, C., Yamazaki, F., and Imamura, F.: Developing Tsunami fragility curves using remote sensing and survey data of the 2010 Chilean Tsunami in Dichato, Nat. Hazards Earth Syst. Sci., 12, 2689-2697, doi:10.5194/nhess-12-26892012, 2012.

Matanle, P.: Ageing and Depopulation in Japan: Understanding the Consequences for East and Southeast Asia in the 21st Century, in: East Asia in 2013: A Region in Transition, White Rose East Asia Centre and Foreign and Commonwealth Office Briefing Papers, edited by: Dobson, H., Sheffield, UK, 30-35, 2014.

Ministry of Land, Infrastructure, Transport and Tourism: White paper on transport policy, Ministry of land, infrastructure, transport and tourism, Tokyo, Japan, 2015.

Onoda, H. and Hayano, K.: SPH simulation of railroad ballast bed slope collapse under inundation flow, Journal of Japan Society of Civil Engineers, Ser. E1 (Pavement Engineering), 71, 97-107, doi:10.2208/jscejpe.71.97, 2015 (in Japanese).

Polemio, M. and Lollino, P.: Failure of infrastructure embankments induced by flooding and seepage: a neglected source of hazard, Nat. Hazards Earth Syst. Sci., 11, 3383-3396, doi:10.5194/nhess-11-3383-2011, 2011.

Railway Technical Research Institute: Standards for railway infrastructure, earthen structures, Maruzen Co. Ltd., Tokyo, Japan, 2007 (in Japanese).

Rath, S. and Bajat, B.: Between sensing, forecasting and risk assessment: An integrated method to model high resolution data for floodplain representations in hydrodynamic simulations, in: Proceedings of the 1st Goettingen Remote Sensing Days, edited by: Erasmi, S., Cyffka, B., and Kappas, M., Goettingen, 7-8 October 2004.

Reed, D. W.: A review of British railway bridge flood failures, Hydrology: Science \& Practice for the 21st Century, 1, 210-216, 2004.

Sakano, A.: Hydraulic study on accumulation of drifting wood at a bridge during a flood, Technical note of National Institute for Land and Infrastructure Management, Ibaraki, Japan, 2003.

Sayama, K., Kobayashi, K., and Takara, K.: The hydrological analysis of the flood due to the typhoon Etau, Technical report on the damage due to the typhoon Etau, Japan Society of Civil Engineers, 2010.

Scawthorn, C., Flores, P., Blais, N., Seligson, H., Tate, E., Chang, S., Mifflin, E., Thomas, W., Murphy, J., Jones, C., and Lawrence, M.: HAZUS-MH Flood Loss Estimation Methodology. II. Damage and Loss Assessment, Natural Hazards Review, 7, 72-81, doi:10.1061/(ASCE)1527-6988(2006)7:2(72), 2006.

Shimozono, T. and Sato, S.: Coastal vulnerability analysis during tsunami-induced levee overflow and breaching by a high-resolution flood model, Coast. Eng., 107, 116-126, doi:10.1016/j.coastaleng.2015.10.007, 2016.

Shinozuka, M., Feng, M. Q., Lee, J., and Naganuma, T.: Statistical Analysis of Fragility Curves, J. Eng. Mech.-ASCE, 126, 1224$1231,2000$.
Steers, J. A., Stoddart, D. R., Bayliss-Smith, T. P., Spencer, T., and Durbidge, P. M.: The Storm Surge of 11 January 1978 on the East Coast of England, Geogr. J., 145, 192-205, 1979.

Suppasri, A., Koshimura, S., and Imamura, F.: Developing tsunami fragility curves based on the satellite remote sensing and the numerical modeling of the 2004 Indian Ocean tsunami in Thailand, Nat. Hazards Earth Syst. Sci., 11, 173-189, doi:10.5194/nhess11-173-2011, 2011.

Suppasri, A., Mas, E., Koshimura, S., Imai, K., Harada, K., and Imamura, F.: Dveloping tsunami fragility curves from the surveyed data of the 2011 great east Japan tsunami in Sendai and Ishinomaki plains, Coast. Eng. J., 54, 1250008, doi:10.1142/S0578563412500088, 2012.

Tachikawa, Y., Shrestha, R., and Sayama, T.: Flood prediction in Japan and the need for guidelines for flood runoff modelling in predictions in ungauged basins, in: International perspectives on the state of the art and pathways forward, IAHS Publ. 301, 7886, 2006.

Tsubaki, R. and Kawahara, Y.: The uncertainty of local flow parameters during inundation flow over complex topographies with elevation errors, J. Hydrol., 486, 71-87, doi:10.1016/j.jhydrol.2013.01.042, 2013.

Tsubaki, R., Kawahara, Y., Sayama, T., and Fujita, I.: Analysis of geomorphic and hydraulic conditions causing railway embankment breach due to inundation flow, Journal of Hydroscience and Hydraulic Engineering, 30, 87-99, https://ir.lib.hiroshima-u.ac.jp/files/public/3/39096/ 20160212131039699174/JHHE_30-1_87.pdf, 2012a.

Tsubaki, R., Kawahara, Y., and Ueda, Y.: An experimental study on railway embankment breach and its critical flow condition, in: 18th Congress of the Asia and Pacific Division of the IAHR, Jeju, Korea, IAHR, 19-23 August 2012b.

Tsubaki, R., Asai, K., Nakamura, A., Tomura, K., Kawahara, Y., and Nagano, H.: Inundation flow in moutanious village in Asa River basin during 2010 July torrential rainfall event, Journal of Japan Society of Civil Engineers, Ser. B1 (Hydraulic Engineering), 70, I_1441-I_1446, doi:10.2208/jscejhe.70.I_1441, 2014 (in Japanese).

Ube Construction Office: Report of design work on the construction section 1 of the disaster prevention work for Asa River, Yamaguchi Prefecture, Japan, 2012.

Ueda, N. and Nakatsuka, H.: The circumstances and the effect of synthetic submersion-under-water damage mitigation measures (Second Dike etc.) in Hijikawa (East Ozu Area), River (Kasen), Japan River Association, 70, 24-27, 2014 (in Japanese).

Vorogushyn, S., Merz, B., and Apel, H.: Development of dike fragility curves for piping and micro-instability breach mechanisms, Nat. Hazards Earth Syst. Sci., 9, 1383-1401, doi:10.5194/nhess-9-1383-2009, 2009.

Wardhana, K. and Hadipriono, F. C.: Analysis of Recent Bridge Failures in the United States, J. Perform. Constr. Fac., 17, 144150, doi:10.1061/(ASCE)0887-3828(2003)17:3(144), 2003.

Yamasaki, T., Yamamoto, H., Tateishi, Y., Harada, Y., Takayama, N., Yoshikoshi, H., and Iwaya, K.: Characteristics of heavy rainfall and water hazard in Yamaguchi on July 15, 2010, Journal of Japan Society for Natural Disaster Science, 29, 413-425, 2010 (in Japanese). 